Review

\title{
An Alternative Cell Therapy for Cancers: Induced Pluripotent Stem Cell (iPSC)-Derived Natural Killer Cells
}

\author{
Li-Jie Hsu ${ }^{1,2}$, Chao-Lin Liu ${ }^{3,4} \mathbb{D}$, Ming-Ling Kuo ${ }^{5,6,7,8}$, Chia-Ning Shen ${ }^{9}$ and Chia-Rui Shen ${ }^{1,2,6,10, * \mathbb{D}}$ \\ 1 Department of Medical Biotechnology and Laboratory Science, College of Medicine, Chang Gung University, \\ Taoyuan 333, Taiwan; D0815001@cgu.edu.tw \\ 2 PhD Program in Biotechnology Industry, College of Medicine, Chang Gung University, Taoyuan 333, Taiwan \\ 3 Department of Chemical Engineering, Ming Chi University of Technology, New Taipei 243, Taiwan; \\ clliu@mail.mcut.edu.tw \\ 4 Biochemical Technology R\&D Center, Ming Chi University of Technology, New Taipei 243, Taiwan \\ 5 Department of Microbiology and Immunology, College of Medicine, Chang Gung University, \\ Taoyuan 333, Taiwan; mingling@mail.cgu.edu.tw \\ 6 Center of Molecular and Clinical Immunology, Chang Gung University, Taoyuan 333, Taiwan \\ 7 Division of Allergy, Asthma, and Rheumatology, Department of Pediatrics, Lin-Kou Chang Gung Memorial \\ Hospital, Taoyuan 333, Taiwan \\ 8 Department of Pediatrics, New Taipei Municipal TuCheng Hospital, New Taipei 236, Taiwan \\ 9 Genomics Research Center, Academia Sinica, Taipei 115, Taiwan; cnshen@gate.sinica.edu.tw \\ 10 Department of Ophthalmology, Lin-Kou Chang Gung Memorial Hospital, Taoyuan 333, Taiwan \\ * Correspondence: crshen@mail.cgu.edu.tw; Tel.: +886-3-211-8800 (ext. 3046/5200)
}

Citation: Hsu, L.-J.; Liu, C.-L.; Kuo, M.-L.; Shen, C.-N.; Shen, C.-R. An Alternative Cell Therapy for Cancers: Induced Pluripotent Stem Cell (iPSC)-Derived Natural Killer Cells Biomedicines 2021, 9, 1323. https:// doi.org/10.3390/biomedicines9101323

Academic Editor:

Ramon Garcia Escudero

Received: 29 July 2021

Accepted: 16 September 2021

Published: 26 September 2021

Publisher's Note: MDPI stays neutral with regard to jurisdictional claims in published maps and institutional affiliations.

Copyright: (C) 2021 by the authors Licensee MDPI, Basel, Switzerland. This article is an open access article distributed under the terms and conditions of the Creative Commons Attribution (CC BY) license (https:/ / creativecommons.org/licenses/by/ $4.0 /)$.

\begin{abstract}
Cell therapy is usually defined as the treatment or prevention of human disease by supplementation with cells that have been selected, manipulated, and pharmacologically treated or altered outside the body (ex vivo). Induced pluripotent stem cells (iPSCs), with their unique characteristics of indefinite expansion in cultures and genetic modifications, represent an ideal cell source for differentiation into specialized cell types. Cell therapy has recently become one of the most promising therapeutic approaches for cancers, and different immune cell types are selected as therapeutic platforms. Natural killer (NK) cells are shown to be effective tumor cell killers and do not cause graft-vs-host disease (GVHD), making them excellent candidates for, and facilitating the development of, "off-the-shelf" cell therapies. In this review, we summarize the progress in the past decade in the advent of iPSC technology and review recent developments in gene-modified iPSC-NK cells as readily available "off-the-shelf" cellular therapies.
\end{abstract}

Keywords: induced pluripotent stem cells (iPSCs); natural killer cells (NK cells); cell therapy

\section{Introduction}

Cell therapy (also called cellular therapy or cytotherapy) is defined as therapy in which cellular material is injected into a patient. It is a technology that relies on replacing diseased or dysfunctional cells with healthy, functioning ones. This idea was initialized in 1931 when Paul Niehans (1882-1971) attempted to cure a patient by injecting material from calf embryos or harvesting cells from young animals or the fetus to treat severely ill patients [1]. Therefore, he is regarded as the inventor of cell therapy even though his claims have never been validated. In fact, this major breakthrough in stem cell research is considered the discovery of hematopoietic stem cells (HSCs), which are broadly applied for treating hematological cancers and various disorders of the blood and immune system in the clinic [2]. Before 2006, people believed that the cells were divided from the "organspecific stem cells" of the tissue in which they resided, and that the cell types were also very limited. In addition, these cells may have irreversibly lost the capacity to generate other cell types. In 2006, Shinya Yamanaka and Kazutoshi Takahashi introduced induced pluripotent stem cells (iPSCs) [3], which can stably proliferate and serve as an unlimited 
source of cells to circumvent the original restriction. In the classification of stem cells, iPSCs are descendants of totipotent cells [4] and can be sufficiently expanded for transplantation use and disease treatment.

Currently, cell therapy can be divided into two categories (Figure 1): (1) stem cell therapy, including HSCs, mesenchymal stem cells (MSCs), iPSCs, adult stem cells and, most controversially, embryonic stem cells; and (2) immune cell therapy, via cell-mediated immunity, by transplanting macrophages [5], T cells [6], dendritic cells (DCs) [7], or NK cells [8] into patients to fight cancer cells [9]. iPSC technology has evolved rapidly and offers new perspectives on the production of immunotherapeutic cellular products. The generation of safe master iPSC lines bearing genetic modifications that confer the desired characteristics of the final product can facilitate the development of "off-the-shelf" cellular therapeutics for more patients and types of malignancy (breast cancer, neuroblastoma, epithelial tumors, melanoma) [10].

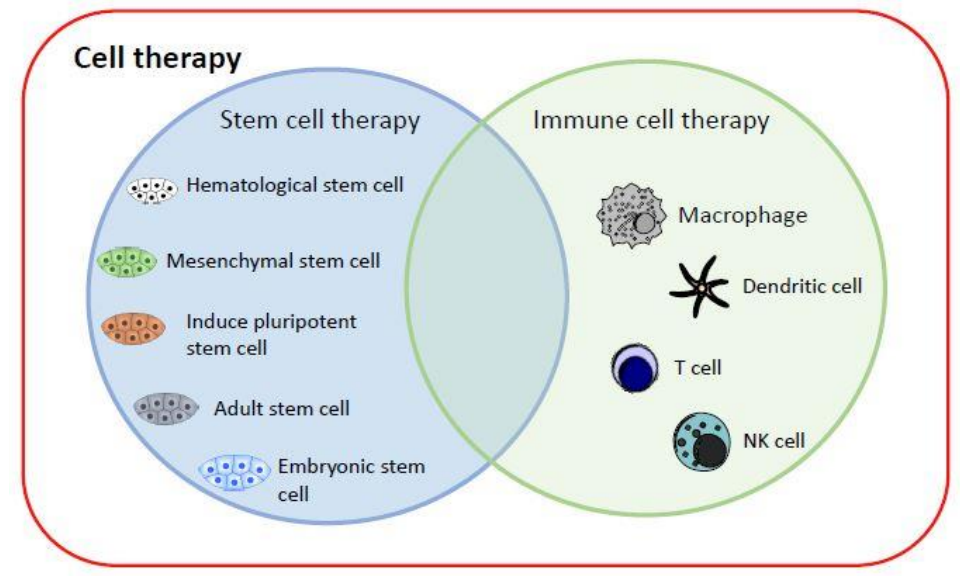

Figure 1. Current cell therapy categories. The major cell therapy categories include stem cell therapy and immune cell therapy. They can replace and repair damaged cells, tissues, and organs in humans, or kill target cells.

Immunotherapy has become a cornerstone in cell therapy and is an innovative approach for the treatment of cancer. The first FDA-approved gene-edited T-cell products (chimeric antigen receptor-modified T, CAR-T) for lymphoma and leukemia came out on the market in 2017 [11]. Recently, CAR-T cell therapy has been successful and become a clinical hotspot in tumor immunotherapy. However, a key challenge for the wider implementation of cell therapy concerns the laborious procedures of identifying HLA-matched healthy related or unrelated donors and harvesting their cells for engineering and infusion into one patient. Additionally, this application is limited by inherent risks such as graft-versus-host disease (GvHD), cytokine release syndrome (CRS), and immune effector cell-associated neurotoxicity syndrome (ICANS) [12]. The process is very lengthy and cumbersome $[13,14]$. Thus, the first clinical trial by Ruggeri et al., who proposed the potent antitumor efficacy of allogeneic NK cells, was performed in the context of hematopoietic stem cell transplantation (HSCT) [15], and the results revealed the potential realization of off-the-shelf products, making CAR NK cell therapies universal products, which might have a better safety profile than CAR-T cell therapy.

At present, it is known that NK cells not only detect and identify malignant cancer cells but also induce cancer cell death and even help trigger a broader adaptive immune response to fully engage and fight tumor cells. The safety of NK cell-based therapies is demonstrated in both autologous and allogeneic haploidentical settings [16-19]. Clinical studies show that NK cells are cytotoxic against a wide range of solid cancer tumor cells in vitro. The antitumor activities of adoptively transferred NK cells in vivo have also been demonstrated in preclinical xenograft mouse models of ovarian cancer, glioblastoma, and metastatic colorectal cancer [20]. NK cell-based immunotherapy has emerged as a promis- 
ing therapeutic approach for hematological malignancies and solid tumors. Currently, NK cells can be derived from autologous or allogeneic sources, such as peripheral blood (PB), and can also be differentiated from induced iPSCs and HSCs [21]. Similar to T cells, NK cells can be engineered to better recognize a specific tumor. However, they have some advantages: they can detect a greater number of chemical signals from tumors than $\mathrm{T}$ cells; they are less prone to attack healthy tissues than T cells are. Thus, NK cell therapy could complement, and in some scenarios substitute for, $\mathrm{T}$ cell-based adoptive therapies to maximize antitumor effects and reduce treatment toxicity [22].

\section{Induced Pluripotent Stem Cells (iPSCs)}

In 2006, Shinya Yamanaka and Kazutoshi Takahashi successfully developed mouse iPSCs by using a retrovirus to deliver "Yamanaka factors" into somatic cells (mouse fibroblasts) [3]. The term "Yamanaka factors" means the combination of four reprogramming transcription factors-Oct3/4, Sox2, c-Myc, and Klf4 [23] - with the capacity to indefinitely propagate in vitro and the ability to differentiate into all somatic cell types upon receiving environmental cues. One year later, Shinya Yamanaka successfully generated iPSCs from human fibroblasts [24]. However, since c-Myc and Klf4 are oncogenes, they increase the risk of chromosomal instability and tumorigenesis. Thereafter, numerous studies have focused on identifying different reprogramming factors $[3,24,25]$. For example, Nanog and LIN28 can replace Klf4 and c-Myc, respectively [26]. Additionally, estrogen-related receptor beta (ESRR $\beta$ ) can replace Klf4 [27]. Currently, iPSCs can be routinely generated from a variety of easily obtainable sources, such as skin and PB [24,28], and employ a combination of different reprogramming factors [24,29-32]. Indeed, a variety of studies have demonstrated the combination of different reprogramming factors utilized in a variety of cell types for the generation of iPSCs [3,24,27-39].

Moreover, scientists are investigating the mechanisms of those transcription factors involved in the generation of iPSCs $[27,31,33,40]$. Currently, it is well known that Oct4, Sox2, and Nanog, when bound together, activate the promoters of both genes (Sox2 and Oct4) and subsequently enhance the stability of pluripotency gene expression [32,41]. In fact, Sox 2 and Oct 4 have attracted attention since the discovery that these genes play critical roles during embryogenesis [42]. Sox2, which is a high-mobility group DNA-binding domain transcription factor, is essential for early embryogenesis in mice [43]. The increased expression ( 2-fold) of Sox2 in embryonic stem cells (ESCs) induces ESC differentiation into cells that express markers of ectoderm and mesoderm, but not endoderm [44]. Oct4 is highly expressed in pluripotent cells and becomes silenced upon differentiation [45], such as by Oct4-deficient embryos, which fail to form an inner cell mass [46]. However, if one of these transcription factors is utilized, no function is detected until they are grouped together in complexes composed of a wide array of other proteins [42].

\subsection{Strategies for Generating iPSCs}

Although reprogramming is inefficient and tedious (the reported range is $0.00002 \sim 1 \%$ in different laboratories), technological advances have led to the tremendous development of nonintegrated viruses [47-54] and nonviral methods [55-58]. The nonintegrated methods include episomal DNA [47], adenovirus [48], Sendai virus [49], piggyBac (PB) transposons [50], small circles [51], recombinant proteins [52], synthetically modified mRNA [53] and microRNAs [54]. Among them, free DNA, synthetic mRNA, and Sendai viruses are commonly used to derive unintegrated iPSCs due to their relative simplicity, high efficiency, and elimination of insertional mutagenesis and transgene reactivation [58]. Nonviral methods, including plasmid transfection [55], minicircle vectors [56], transposon vectors [57], and liposomal magnetofection (LMF) [56] are also relatively safe due to the absence of, or minimal, integration possibilities, but are limited by their low efficiency and slow kinetics. Therefore, these techniques are improved to overcome various bottlenecks for their efficiency [59]. In summary, they are all able to undergo essentially unlimited expansion in vitro without losing pluripotency. 
It appears that reprogramming towards iPSCs also benefits the introduction of genes into iPSCs and enables the correction of disease-causing gene mutations in patient-derived iPSCs or the delivery of specific mutations into non-disease-affected wild-type iPSCs. This process helps to create iPSC-based disease cell models, which could be beneficial for new drug screenings [60]. iPSC-based drug screening platforms are especially helpful for complicated or unintelligible diseases such as Parkinson's disease [61,62], Alzheimer's disease $[63,64]$ and spinal cord injuries $[65,66]$. Figure 2 summarizes the generation of iPSCs and applications.

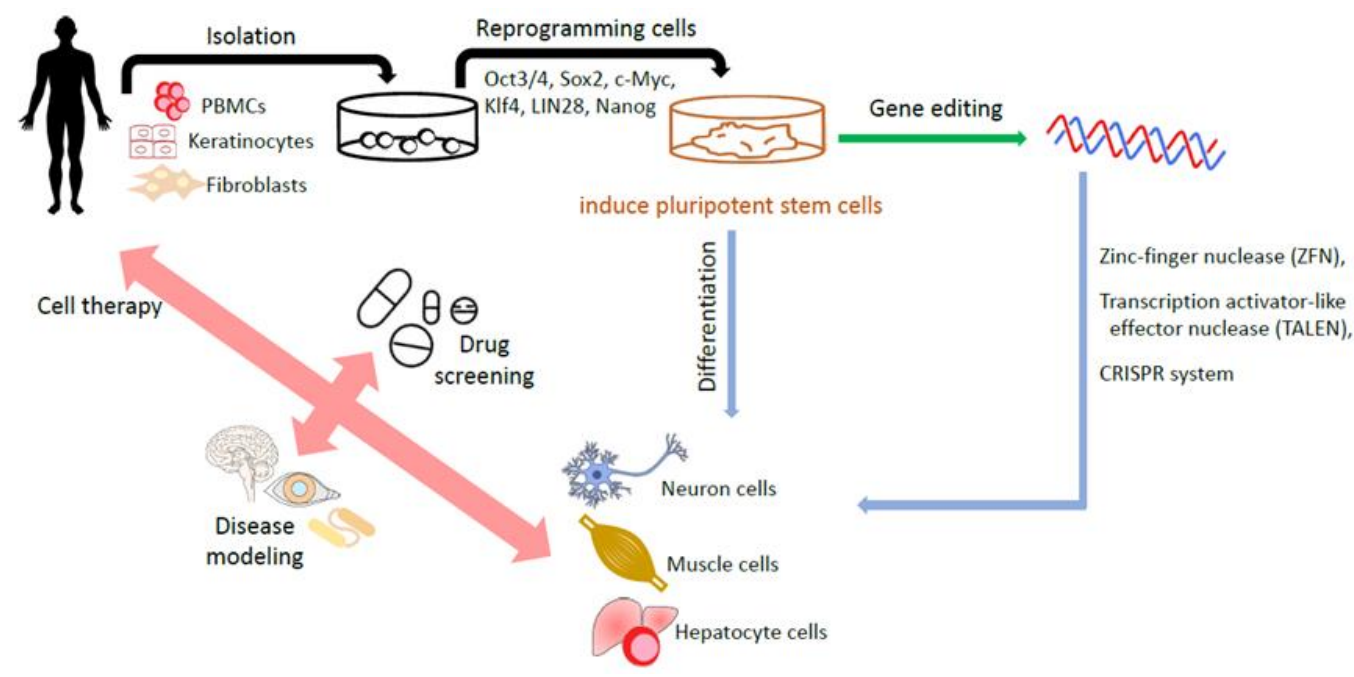

Figure 2. Generation of human iPSCs and their applications. The somatic cells including fibroblasts and isolated from a patient are reprogrammed into iPSCs by transduction with the reprogramming factors. The gene editing technology helps to create iPSCs-based disease cell model. Eventually, iPSCs, with or without edited modifications, are differentiated into various target cells for disease modeling, drug screening, and cell therapy.

Gene editing technology is a next-generation stem cell therapy. Nuclease-based gene editing systems, including zinc-finger nucleases (ZFNs), transcription activator-like effector nucleases (TALENs) and the CRISPR-Cas9 system, are among the most commonly used [67]. CRISPR-Cas9 technology in particular has attracted much attention and gained wide usage in the gene editing of human ESCs [68,69] and iPSCs [70,71], owing to its simplicity of design and ease of use. It is defined by a guide RNA that binds to the Cas nuclease and facilitates the design of new targeting constructs [72]. Unlike CRISPR-Cas9, ZFN and TALEN systems require the dimerization of the attached Fok1 endonuclease to induce their targeted double strand breaks (DSBs) [73]. However, the above technologies encounter several challenges. The major challenge is the "off-target effect", which may induce unintended responses, leading to the risk of disaster damage. The societal challenge is how to mitigate the sense of uncertainty and fear of catastrophic misuse [74]. The first clinical trials (NCT03655678 and CT03745287) involving ex vivo "CRISPR-Cas9 genome editing in HSCs" for the treatment of hemoglobinopathies were initiated in 2018 [75,76]. Since off-target effects remain a challenge for the clinical translation of CRISPR, it is important to develop ultrasensitive methods to identify them. "Prime editing" based on RNA uses a modified Cas 9 coupled to an engineered reverse transcriptase to make precise modifications in genomic sequences without creating DSBs [77-79]. The precision and versatility of prime editing may allow it to rival the CRISPR system as the preferred genomic editing tool [67].

\subsection{Clinical Application of iPSC-Derived Products}

Cell therapy appears to be the best or most common alternative choice of available treatments for some diseases. However, immune rejection is the major challenge. Due to the autologous cell source, this is a privilege of iPSC-derived products in regenerative medicine. 
Autologous iPSCs are immunologically identical to the host and can be established from host somatic cells and differentiated into a variety of cell types for cell therapy, including immune cells such as natural killer (NK) cells and macrophages. The bank for storing iPSC cell lines was established according to donors with identified human leukocyte antigen (HLA) and has become an effective way to provide recipients with the maximum number of HLA-matched cell products derived from iPSC lines [80].

In 2014, the world's first clinical trial in Japan was performed based on allogeneic iPSCs, in which retinal pigment epithelial (RPE) cells derived from allogeneic iPSCs were transplanted into a patient with age-related macular degeneration (AMD) [81,82]. The 2-year follow-up trial demonstrated that the AMD patient's visual acuity improved and was stable due to the reprogrammed cells, which remained intact. In addition, no serious adverse effects on transplanted iPSC-derived RPE cells were observed [83]. In summary, HLA is a molecule that enables the immune system to distinguish between self and nonself entities, and HLA compatibility is positively correlated with graft survival rates after transplantation [84]. However, the establishment of autologous iPSCs from individual patients validated for clinical use is costly and time-consuming and hampers the standardization of the therapy. Therefore, Japan and the European Union are promoting the use of clinicalgrade allogeneic iPSCs, which are established from the peripheral blood mononuclear cells of HLA-matched healthy donors and are less susceptible to immune rejection. The iPSC bank in Japan reported that the stock of their iPSCs was able to cover approximately $32 \%$ of the Japanese population in view of HLA matching for clinical use and the targeting of various diseases in 2018 [85].

Global trends in clinical trials including pluripotent stem cells involve ophthalmic diseases, cardiovascular diseases, neurological disorders, metabolic diseases, genetic syndromes, reproductive and urogenital diseases, hematologic disorders, otorhinolaryngologic diseases and defects in the immune system [86]. Additionally, they can be applied for the treatment of spinal cord injury (SCI) [87-89], which is considered a refractory traumatic disease. However, with recent advances in stem cell transplantation, the field of regenerative medicine has gained hopeful momentum in developing a novel treatment for this challenging pathology. SCI usually results in permanent disability, and its symptoms include a loss of muscle function, sensation, or autonomic function in the parts of the body served by the spinal cord [87]. Hideyuki $\mathrm{O}$ et al. reported the first study to investigate the therapeutic efficacy and safety of human iPSC-neural precursor cell (NPC) transplantation for animal SCI models [90]. In 2018, the Keio University Certified Special Committee for Regenerative Medicine approved the unintegrated human iPSC product for clinically treating SCI patients with the ASIA impairment score A [91].

iPSCs are established from patients across a panoply of diseases, leading to the development of a wide range of cell-based disease models, which are beneficial for understanding the pathogeneses of diseases and facilitating drug discovery. For example, histone deacetylase 4 (HDAC4) is shown to be mislocalized in patient iPSC-derived dopaminergic neurons, which model Parkinson's disease and cause the downregulation of some critical genes [92]. Alternatively, adoptive immunotherapy with iPSC-derived immune effector cells (dendritic cells (also called DCs), tumor-specific T cells and NK cells) is also applied to cancer treatments [93-97], some examples of which are provided as follows:

1. iPSC-DCs: In the study by Senju $S$ et al., a method was developed to generate DCs from human iPSCs. These iPSC-DCs have the characteristics of original DCs, including the capability of T-cell stimulation, processing and presenting antigens, and producing cytokines [93]. Kitadani J et al. successfully established iPSC-DCs from the fibroblasts of healthy donors, as well as mouse iPSC-DCs from the iPS cell line iPSMEF-Ng-20D-17 [94], which were derived from C57/BL6 MEFs. They demonstrated the therapeutic potential of mouse iPSC-DCs, in which the carcinoembryonic antigen (CEA) was transduced and expressed in a subcutaneous tumor model using CEA transgenic mice. These findings indicate that genetically modified iPSC-DCs, inducing 
the expression of CEA, are a promising strategy for the treatment of gastrointestinal cancer.

2. iPSC-T: Adoptive immunotherapy with antigen-specific cytotoxic T lymphocytes (CTLs) represents a potential therapeutic strategy that can reduce tumor development and provide a survival advantage for patients undergoing cancer therapies. Maeda $\mathrm{T}$ et al. developed a simple method to generate antigen-specific CD8 $\alpha \beta \mathrm{T}$ cells from the iPSCs of healthy volunteers and demonstrated their therapeutic potential against leukemia [95]. Wilms' tumor antigen 1 (WT1)-specific CTLs regenerated by this method demonstrated antigen-specific cytotoxic activity in vitro and showed comparable potential to primary CTLs in producing IFN $\gamma$ and $\mathrm{TNF} \alpha$ [94]. When applied in vivo in a xenograft model, these CTLs prolonged the survival of mice bearing WT1-expressing leukemic cells [94]. Recent advances show the potential of the chimeric antigen receptor (CAR)-transduced T-cell immunotherapy for the treatment of a wide variety of diseases. Themeli $\mathrm{M}$ et al. demonstrated in clinical trials that CD19 CAR-modified T cells efficiently induce a complete remission in patients with acute or chronic lymphoblastic leukemias and eradicate B-cell malignancies in mice [96].

3. iPSC-NK: The multiple dosing of allogeneic iPSC-NK cell therapy succeeded in treating solid tumors, such as ovarian cancer $[97,98]$. Hermanson D et al. established iPSCs derived from umbilical cord blood CD34+ cells, UCBiPS7, and derived iPSC-NK cells via spin embryoid bodies [98]. iPSC-NK cells were applied to treat $\mathrm{NOD} / \mathrm{SCID} / \mathrm{\gamma c}^{-/-}$(NSG) mice, which were inoculated with ovarian cancer cells (MA148), and the median survival improved from 73 to 98 days. Moreover, such iPSC-NK cells were found in the peritoneal cavity of mice and were able to markedly inhibit tumor growth [97], indicating the therapeutic potential of iPSC-NK cells for treating solid tumors.

Although iPSC-Ts provide an alternative cell source for allogeneic T-cell immunotherapy, they appear to have poor outcomes and severe side effects [99,100]. Experimental mice receiving iPSC-T treatment died of tumor relapse and/or graft-versus-host disease (GvHD) [99]. In fact, it is reported that patients may develop cytokine release syndrome (CRS) and/or immune effector cell-associated neurotoxicity syndrome (ICANS) [100]. In addition, although more effective than traditional chemotherapy, T cell therapies are usually costly (approximately USD 373-475,000 per dose), require longer preparation times, and partly depend on the quality of the cell source after leukapheresis [101]. However, NK cells function as allogeneic effectors and do not need to be collected from a patient or a specific HLA-matched donor to reduce GvHD [102]; therefore, it is not necessary to spend much effort preparing autologous NK cells, and off-the-shelf sources of allogeneic iPSC-NK cells may become available. Several trials have demonstrated that $30-50 \%$ of patients with refractory or relapsed acute myelogenous leukemia (AML) can achieve complete remission after receiving allogenic NK cells [16] stimulated with cytokines (typically IL-2 or IL-15) [103].

\subsection{Generation of iPSC-Derived NK Cells}

Recently, several generation methods have been described to mass-produce iPSC-NK cells to provide unlimited NK cells for research or clinical applications, and the representative NK cells are summarized in Table 1:

1. PB-iPSCs with OP9: On day 0, iPSCs derived from peripheral blood cells (PB-iPSCs) were cocultured with OP9 cells (a bone marrow stromal cell line) in $\alpha \mathrm{MEM}$ with $20 \%$ fetal bovine serum (FBS). On day 12, the modified OP9 cell line expressing Notch ligand Delta-like-1 (OP9-DLL1) replaced OP9 cells and was cocultured with the above iPSCs (mainly CD34+) in the presence of the stem cell factor (SCF) and Flt3L, together with IL-7 and IL-15. On day 26, a small population of CD45+CD56+ cells appeared; the CD45+CD56+ cells became the dominant population, with a purity of $99 \%$ on day 40 . A yield of $7.93 \times 10^{6}$ CD45+CD56+ cells was obtained on day 40 and increased to $15 \times 10^{6}$ cells on day 47 [104]. 
2. FB-iPSCs with OP9: On day 0, the iPSC cell line from primate skin fibroblasts (FBiPSCs) was cocultured with OP9 in $\alpha$ MEM containing $20 \%$ FBS and supplemented with a basic fibroblast growth factor (bFGF), activin A, vascular endothelial growth factor (VEGF) and CHIR99021. On days 6 and 8, SCF, thrombopoietin (TPO), IL-3 and IL- 6 were added to the above culture medium for the differentiation of mesodermal cells to hematopoietic stem cells. On day 10, the floating cells were harvested and cocultured with the modified OP9 cell line expressing Notch ligand Delta-like-4 (OP9DLL4) in $\alpha$ MEM containing 20\% FBS, in addition to IL-7, FLT3L and IL-2 for up to 4 weeks. On day 38 , a yield of 1.0-3.5 $\times 10^{6}$ iPSC NK cells expressing perforin and IFN $\gamma$ was obtained [105].

3. CB-iPSC: On day 0, UCBiPS7 iPSCs derived from umbilical cord blood CD34+ cells were seeded in round-bottomed plates for the development of embryoid bodies in a BPEL culture medium (bovine serum albumin, polyvinyl alcohol, essential lipids) containing SCF, VEGF and bone morphogenic protein 4 (BMP-4). During days 8-12, the formed embryoid bodies (EBs) containing CD34+CD43+ cells were directly transferred into flat-bottomed plates, and BPELs were cultured in the presence of IL-3, IL-7, IL-15, SCF and FLT3L. After 28 32 days, iPSC-NK cells were obtained and expanded in RPMI-1640 containing 10\% FBS, 1\% penicillin/streptomycin and 50 units/mL IL-2 and stimulated with irradiated (10,000 cGy) artificial antigen-presenting cells (aAPCs) $(2: 1 \mathrm{v} / \mathrm{v})$ upon initiation of culture. The culture medium was changed twice weekly, and iPSC-NK cells could be restimulated with aAPCs every 7 days. The purity of the expanded NK cells almost reached 97\% [97].

4. CB-iPSC: On day 0, the iPSC cell lines 409B7 (B7) and CB-A11 (A11), derived from cord blood mononuclear cells, were seeded in iMatrix 511-coated plates (Osaka, Japan) for the development of EBs in an Essential 8 culture medium supplemented with CHIR99021, BMP-4, and VEGF. On day 2, the formed EBs containing CD34+ cells were cultured in an Essential 6 culture medium containing SB431542, SCF, and VEGF. During days 4-12, the formed EBs appeared to contain CD34+, CD43+ and CD45+ hemoangiogenic progenitor cells (HPCs) and were cultured in a Stem Line II medium together with SCF and Flt3L. From day 12 onwards, the cells were cultured in DMEM containing 20\% human AB serum or a Stem Line II, in addition to SCF, Flt3L, IL-7 and IL-15. On day 48, the purity of iPSC-NK cells reached $63.10 \pm 7.01 \% \sim 78.23 \pm 5.66 \%$ [106].

Table 1. Generation methods for iPSC-derived NK cells.

\begin{tabular}{|c|c|c|c|c|c|c|c|c|}
\hline & \multicolumn{3}{|c|}{ Primary Differentiation } & \multicolumn{3}{|c|}{ Lymphoid Commitment } & \multirow{2}{*}{$\begin{array}{c}\text { Yield } \\
\left(\text { per } 1 \times 10^{6}\right. \\
\text { iPS cells) }\end{array}$} & \multirow[t]{2}{*}{ Reference } \\
\hline & Medium & Cytokine & Culture Day & Medium & Cytokines & Culture Day & & \\
\hline 1 & $\begin{array}{l}\alpha \mathrm{MEM}+ \\
20 \% \text { FBS }\end{array}$ & - & 12 & $\begin{array}{l}\alpha \mathrm{MEM}+ \\
20 \% \text { FBS }\end{array}$ & $\begin{array}{l}\text { SCF, Flt3L, } \\
\text { IL-7, IL-15 }\end{array}$ & 47 & $15.0 \times 10^{6}$ & {$[104]$} \\
\hline 2 & $\begin{array}{l}\alpha \mathrm{MEM}+ \\
20 \% \text { FBS }\end{array}$ & $\begin{array}{c}\text { bFGF, } \\
\text { activin } \mathrm{A}, \\
\text { VEGF, } \\
\text { CHIR99021 }\end{array}$ & 10 & $\begin{array}{l}\alpha \mathrm{MEM}+ \\
20 \% \text { FBS }\end{array}$ & $\begin{array}{c}\text { Flt3L, } \\
\text { IL-7, IL-2 }\end{array}$ & 38 & $1.0 \sim 3.5 \times 10^{6}$ & {$[105]$} \\
\hline 3 & $\begin{array}{c}\text { BPEL } \\
(\mathrm{APEL}+10 \% \\
\text { FBS })\end{array}$ & $\begin{array}{c}\text { SCF, VEGF, } \\
\text { BMP-4 }\end{array}$ & 11 & BPEL & $\begin{array}{c}\text { SCF, Flt3L, } \\
\text { IL-3, IL-7, } \\
\text { IL-15 }\end{array}$ & $28 \sim 32$ & $>97 \%$ & [98] \\
\hline \multirow{3}{*}{4} & Essential 8 & $\begin{array}{c}\text { BMP-4, } \\
\text { CHIR99021, } \\
\text { VEGF }\end{array}$ & $0-2$ & \multirow{3}{*}{$\begin{array}{l}\text { DMEM + } \\
20 \% \text { human } \\
\text { AB-serum or } \\
\text { Stem line II }\end{array}$} & \multirow{3}{*}{$\begin{array}{l}\text { SCF, Flt3L, } \\
\text { IL-7, IL-15 }\end{array}$} & \multirow{3}{*}{48} & \multirow{3}{*}{$\begin{array}{c}63.10 \pm \\
7.01 \% \sim 78.23 \\
\quad \pm 5.66 \%\end{array}$} & \multirow{3}{*}[106]{} \\
\hline & Essential 6 & $\begin{array}{c}\text { SCF } \\
\text { SB431542, } \\
\text { VEGF }\end{array}$ & $2-4$ & & & & & \\
\hline & Stem line II & SCF, Flt3L & $4-12$ & & & & & \\
\hline
\end{tabular}

ND: non data. CHIR99021 is an aminopyrimidine derivative that is an extremely potent glycogen synthase kinase (GSK) 3 inhibitor, inhibiting both GSK3 $\beta$ and GSK3 $\alpha$. SB431542 is a selective and potent inhibitor of the TGF- $\beta$ /Activin/NODAL pathway that inhibits ALK5, ALK4 and ALK7 by competing for the ATP binding site. Both are commonly used to maintain human and mouse stem cell lines. 
Recently, biotechnology has advanced to the point where NK cells can be generated directly from CD34+ HSCs and iPSCs. However, the different culture methods might give rise to different subsets of NK cells. Therefore, there is an urgent need to standardize the phenotyping protocol because the specific phenotypes may be associated with the function of NK cells, which is critical for the therapeutic applications of NK cells [107].

\section{Natural Killer Cells (NK cells)}

NK cells are a type of lymphocyte (a white blood cell) that was first described in the mid 1970s as an innate immune cell and recently reclassified as a member of the group 1 innate lymphoid cells (ILCs) [108]. Five major groups of ILCs have been defined on the basis of their cytokine production patterns and developmental transcription factor requirements: natural killer (NK) cells, group 1 ILCs (ILC1s), ILC2s, ILC3s and lymphoid tissue-inducer (LTi) cells. ILC1s, ILC2s and ILC3s resemble the corresponding T helper cell subsets (T helper 1 (TH1), TH2 and TH17 cells, respectively) and produce cytokines that shape both innate and adaptive immune responses [109]. They are able to recognize stressed cells in the absence of antibodies and the major histocompatibility complex (MHC), allowing for a much faster immune reaction. NK cells are typically activated by missing MHC class I marker-harmful cells, which play a very important role. Missing MHC class I cells cannot be detected and destroyed by other immune cells, such as T lymphocytes [109-112].

\subsection{The Physiological Conditions in NK Cells}

NK cells differentiate from and mature in the bone marrow (BM), lymph nodes (LNs), spleen, tonsils, and thymus and then enter the circulation. In humans, they are typically characterized as CD56+CD3 ${ }^{-}$lymphocytes and can be broadly categorized into two subpopulations based on the level of CD56 and CD16 (Fc receptor FcR III) expression: CD56 ${ }^{\text {bright }} /$ CD16 ${ }^{\text {neg }}$ cells and CD56 ${ }^{\text {dim }} / C D 16^{\text {pos }}$ cells (Figure 3 ). Previous studies have suggested that CD56 $6^{\text {bright }} / \mathrm{CD} 16^{\text {neg }}$ cells are immature precursors of mature CD56 ${ }^{\mathrm{dim}} / \mathrm{CD} 6^{\text {pos }}$ cells [113-115]. The majority of PB-NK cells are CD56 ${ }^{\mathrm{dim}} / \mathrm{CD} 16^{\mathrm{pos}}$ cells, which are highly cytotoxic against target cells. In contrast, approximately $2-10 \%$ of PB-NK cells are CD56 $6^{\text {bright }} /$ CD16 $6^{\text {neg }}$ cells, which have a low cytotoxic activity while displaying a high capacity to produce immune regulatory cytokines (such as IFN $\gamma, \mathrm{TNF}$, and GMCSF) [116], interacting with dendritic cells and T-cell polarization to participate directly in adaptive immune responses [117]. The unique characteristic of the metabolism of NK cells is that they do not use glutamine as a fuel to drive oxidative phosphorylation (OXPHOS). In fact, ATP production is primarily fueled by glucose. The inhibition of OXPHOS or glycolysis in NK cells significantly impairs IFN $\gamma$ production in a short time [111].

Mature NK cells are known as CD56 ${ }^{\mathrm{dim}} / \mathrm{CD} 16^{\text {pos }}$ cells that can trigger antibodydependent cellular cytotoxicity (ADCC), which is known as one of the important functions of NKs. In fact, several different mechanisms are involved in the NK-mediated lysis of target cells [118,119], including (1) the release of cytoplasmic granules containing perforin and granzymes, (2) the production of IFN- $\gamma$, (3) the expression of FasL and TRAIL, and (4) the expression of ADCC. For example, in tumor cell therapy, the type III Fc-gamma receptor $(\mathrm{Fc} \gamma \mathrm{R})$, also known as $\mathrm{CD} 16$, on NK cells recognizes the Fc portion of antibodies bound to tumor cells and triggers the cell death of tumor cells through ADCC. This antibody may be a monoclonal antibody $(\mathrm{mAb})$, preferentially of class IgG1 or IgG3 since these two antibodies are able to link different Fc $\gamma$ Rs [120]. Over 100 monoclonal antibodies (mAbs) on the market involving several mechanisms of action are used as tumor cell therapeutics [121], in addition to NK cell-mediated ADCC, including checkpoint inhibitors, targeting radiation, blocking cell growth, inhibiting neovascularization and inducing leukocyte effector functions [120,122,123]. 


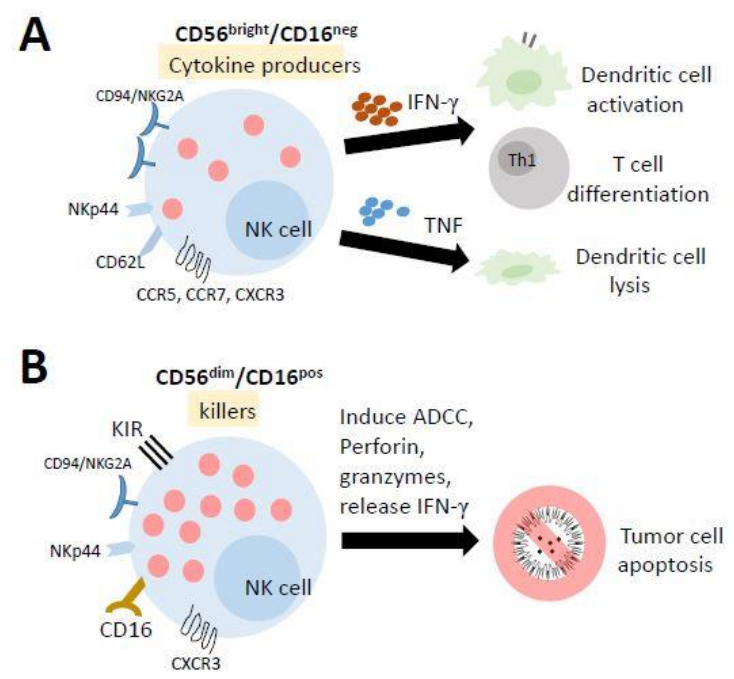

Figure 3. The mature human natural killer (NK) cells and their functions. NK cells differentiate from and mature in the bone marrow, lymph nodes, spleen, tonsils, and thymus and then enter the circulation. (A) Most of the cells in the lymph nodes (LN) and tonsils have a lower cytotoxic activity while displaying a high capacity to produce several cytokines. They promote the activation of dendritic cells and the polarization of Th1 cells by releasing IFN- $\gamma$, while TNF production results in the lysis of immature DCs. (B) The cells in the peripheral blood (PB) and spleen are highly cytotoxic against target cells. They can trigger antibody-dependent cellular cytotoxicity (ADCC) to kill target cells.

\subsection{NK Cell Education}

NK cell activity is tightly regulated by a complex interplay between activating and inhibitory receptors that prevent the killing of normal autologous cells expressing an appropriate level of all self-HLA alleles and low/negative levels of ligands for non-HLAspecific activating receptors (aNKRs) [124]. The most frequently described activating receptor is natural killer group 2D (NKG2D, a transmembrane protein), which belongs to the natural cytotoxic receptor (NCR) family. The other family members include NKp46, NKp30, and NKp44, and the leukocyte adhesion molecule DNAX accessory molecule-1 (DNAM1, also called CD226). These receptors, expressed largely on NK cells, are potent inducers of NK cell cytotoxicity, and are crucial for NK cell-mediated tumor apoptosis. It is known that the expression of NKp44 is induced upon NK cell activation, while NKp46 and NKp30 are expressed on both resting and activated NK cells [125].

There are two main inhibitory receptors, the killer immunoglobulin-like receptor (KIR) family, which can bind HLA-class I, and the heterodimeric receptors CD94-NKG2A/B, which recognize HLA-E [124,126,127]. In malignancies, activating killer cell immunoglobulin-like receptors (KARs) are often decreased, while the expression of the most prominent inhibitory NK cell receptors, KIRs and CD94/NKG2A, may occasionally increase [128,129]. Remarkably, NK cell activation is determined by the balance of inhibitory and activating receptor stimulation $[129,130]$. Indeed, in the absence of inhibitory interactions, NK cells kill target cells and produce cytokines in great quantities [128]. By secreting large amounts of cytokines and chemokines, mature NK cells can not only directly kill target cells but can also elicit other immune cells, including monocytes, DCs, and T cells. Similarly, naïve NK cells can also be activated by different proinflammatory cytokines, such as IL-2, IL-15, IL-18 or IL-21, which stimulate NK cell survival and proliferation, as well as upregulating the expression of activating receptors and enhance NK cell cytotoxicity [109,110].

NK cells can recognize tumor cells and have antitumor and antimetastatic potential in cancerous cells [131]. The chemoattractant/receptor axes appear to control tumorinfiltrating NK cell migration, activation, survival, and persistence in the tumor microenvironment [132]. In the context of NK cells, chemokine receptors of note include CCR2, CCR5, CCR7, CXCR3, and CX3CR1 [133]. CCR2 and CCR5 regulate the migration of tumorassociated monocytes and macrophages. The cytolytic activity of NK cells is simultaneously 
augmented by CCL2 [134]. High levels of CCL2 correlate with increased monocyte and macrophage recruitment and appear to be an indicator of an adverse prognosis in patients with breast, ovarian, gastric, and esophageal carcinomas [135,136]. The presence of tumorinfiltrating NK cells confers a favorable outcome in many tumors. However, due to nutrient and oxygen deprivation, a higher concentration of tumor-derived metabolism causes the metabolic impairment of NK cells, which ultimately limits their effector functions [137].

\subsection{NK Cell-Based Therapy in Tumors}

Many trials of adoptive NK cell-based immunotherapy have been performed over the past decade and growing clinical and experimental evidence highlights the clear and direct role of NK cells in controlling human cancer development and/or progression. Epidemiologic studies indicate that a reduced function of NK cells is related to cancer incidence [107]. Endogenous NK cells in cancer patients usually have impaired function because of the alteration of the receptor repertoire in the cells. Therefore, the primary method in immunotherapy treatments is to "push" for immune activation by including additives such as cytokines (IL-2 therapy [138], IL-15 therapy [139] and TGF $\beta$ inhibitors [140]) and antibodies that help to modulate the mechanisms that improve the quantity and/or quality of the antitumor immune response. For example, some immunomodulatory drugs targeting NK cells, such as lenalidomide and pomalidomide, are approved for the treatment of multiple myeloma, mantle cell lymphoma and a subset of myeloid-derived suppressor cells (MDSCs). These drugs induce cell cycle arrest and apoptosis in tumor cells. Moreover, they increase NCR expression, expand NK cell populations and increase the immune cell recognition of tumor cells in various models. Lenalidomide, for instance, is shown to decrease the immunosuppressive activity of MDSCs and regulatory $\mathrm{T}$ (Treg) cells and to increase NK cell cytotoxicity and IFN $\gamma$ production. NK cell dysfunction in patients with chronic myeloid leukemia (CML) is associated with immune evasion and disease progression, but tyrosine kinase inhibitor (TKI) treatment can restore NK cell numbers and functions [141].

However, NK cell-mediated control of large solid tumors is usually inefficient, although tumors often express large amounts of activating ligands and low levels of inhibitory ligands, presumably due to tumor escape through the alteration of NK cell function and resistance. Currently, the augmentation of the receptor affinity and activation of ADCC and accessibility to the tumor site, in combination with other molecules and immunemodulatory strategies, such as radiotherapy and checkpoint blockade, might be good targets for NK cell-mediated attack. A new type II glycoengineered anti-CD20 mAb with increased Fc $\gamma$ R III binding and ADCC is represented by obinutuzumab (GA101). GA101 induces NK cell activation regardless of the inhibitory immunoglobulin-like receptor (KIR) expression. Furthermore, its activity is not adversely modulated by KIR/HLA [120]. Monalizumab (IPH2201), an anti-NKG2A checkpoint inhibitor, has been evaluated in clinical trials in ovarian cancers, head and neck cancers, advanced malignancies and chronic lymphocytic leukemia (CLL). Its use might represent a novel approach in NK-based immunotherapy, not only by enhancing the cytotoxic potential of the cells but also by potentially proposing a role for them in ADCC augmentation [120].

Conversely, many studies have described the engineering of NK cells with CARs to improve the killing of solid tumors, and clinical trials utilizing CAR-expressing NK cells for the treatment of both hematological malignancies and refractory solid tumors have been initiated (ClinicalTrials.gov: NCT00995137, NCT01974479, NCT02839954, NCT02892695, NCT02742727, and NCT02944162, https:/ / clinicaltrials.gov/, accessed on 29 July 2021). Most of these studies use CARs designed for T cells that are expressed in NK cells. However, due to the limitations of CAR-T cell therapy and the patient's specific clinical and diseaserelated features, a decision was made to take an alternative approach to using CAR natural killer (NK) cells that might circumvent these problems [141,142]. Even though allogeneic iPSC-NK cell therapy requires multiple doses for the treatment of solid tumors, genetic 
modifications, CAR-NK can further improve the specificity, strength, and efficacy of iPSCCAR NK cell therapies [141].

Indeed, there is an increasing interest in iPSC-NK therapies due to their ability to address the supply chain bottlenecks associated with primary and cell line NK therapies (Table 2). The advantages of iPSCs include their ease of generation from accessible sources such as fibroblasts or peripheral blood, the retention of pluripotency during expansion, and the capacity for long-term storage. The FDA has already approved a phase I clinical trial to investigate Fate Therapeutics' off-the-shelf iPS-NK product, FT500, representing the first FDA-approved clinical investigation of an iPS-derived cell product in the USA. To generate this product, NK cells were developed from a clonal master iPSC line cell bank. FT500 in combination with checkpoint blockade therapy was utilized to treat adults with advanced solid tumors (ClinicalTrials.gov: NCT03841110). FT516, engineered to include a high affinity, noncleavable CD16 (hnCD16) Fc receptor, was designed against hematological malignancies (ClinicalTrials.gov: NCT04023071). In the preclinical FT538 study, NK cells were engineered by the knockout of the CD38 receptor and knock-in of the high-affinity, noncleavable CD16 receptor and the fused IL-15 receptor. The cells were used in combination with daratumumab (anti-CD38) monoclonal antibody to treat multiple myeloma [101].

Table 2. iPSC-NK cell therapy for cancers.

\begin{tabular}{|c|c|c|c|}
\hline \multicolumn{4}{|c|}{ Pre-Clinical Research } \\
\hline Disease target & Strategies & Outcome & References \\
\hline Ovarian cancer & Multiple dose, IL-2 stimulated & $\begin{array}{l}\text { The median survival improved from } 73 \\
\text { to } 98 \text { days }\end{array}$ & [97] \\
\hline $\begin{array}{c}\text { Cell line } \\
\text { (K562, SKOV3, SW480, } \\
\text { HCT-8, MCF7, SCC-25) }\end{array}$ & IL-2 stimulated & $\begin{array}{l}\text { Efficiently killed all tested cancer cell } \\
\text { lines }(p<0.5)\end{array}$ & {$[105]$} \\
\hline Ovarian cancer & $\begin{array}{c}\text { Targeting Mesothelin, engineered with chimeric, } \\
\text { NKG2D-CAR-iPSC-NK }\end{array}$ & $\begin{array}{c}\text { NKG2D-CAR-iPSC-NK cells displayed } \\
\text { in vivo function similar to } \\
\text { NKG2D-CAR-iPSC-T cells }\end{array}$ & {$[141]$} \\
\hline $\begin{array}{l}\text { Hematological cancers, } \\
\text { Hepatocellular } \\
\text { carcinomas, Ovarian } \\
\text { cancer }\end{array}$ & $\begin{array}{l}\text { Tetravalent bispecific trifunctional antibody } \\
\text { targeting GPC3, NKp46-CAR-iPSC-NK-EGFR }\end{array}$ & $\begin{array}{l}\text { Effectively suppressed GPC3-expressing } \\
\text { tumor growth in vitro and in vivo and } \\
\text { confirmed the therapeutic quality and } \\
\text { safety of the final product }\end{array}$ & {$[142]$} \\
\hline \multicolumn{4}{|c|}{ Clinical trial } \\
\hline NCT number & Disease target & Start date & Affiliation \\
\hline NCT03841110 & $\begin{array}{c}\text { Advanced solid tumors } \\
\text { Lymphoma, Gastric cancer, Colorectal cancer, } \\
\text { Head and neck cancer, Squamous cell } \\
\text { Carcinoma } \\
\text { EGFR positive solid tumor, HER2-positive breast } \\
\text { cancer, Hepatocellular, Small cell lung cancer, } \\
\text { Renal cell carcinoma, Pancreas cancer, Melanoma, } \\
\text { NSCLC, Urothelial carcinoma, Cervical cancer, } \\
\text { Microsatellite instability, Merkel cell carcinoma }\end{array}$ & 15-Feb-19 & $\begin{array}{l}\text { Fate } \\
\text { Therapeutics }\end{array}$ \\
\hline NCT04023071 & Acute myelogenous leukemia, B-cell lymphoma & 4-Oct-19 & Fate Therapeutics \\
\hline NCT04614636 & $\begin{array}{l}\text { Multiple myeloma Relapsed/Refractory acute } \\
\text { Myeloid leukemia, Acute myelogenous leukemia }\end{array}$ & 4-Nov-20 & Fate Therapeutics \\
\hline
\end{tabular}

As of the data cutoff date of April 16, 2021, the encouraging outcome for pateints in both trials of FT516 and FT538 was observed. Four patients in FT516 $(n=9)$ and one in FT538 $(n=3)$, respectively, achieved an objective response with complete leukemic blast clearance in the bone marrow. None of them observed dose-limiting toxicities and no events were of any grade of CRS, ICANS, or GvHD. Recently, a third-generation anti-GPC3-CAR 28bbz has demonstrated safety and efficacy in disseminating ovarian tumors [143]. Being engineered with chimeric antigen receptors, the iPSC-NK cells appears to be more effective 
at binding to cancer-specific antigens, enhancing the therapeutic efficacy for solid tumors, and providing perspectives for its clinical uses.

\section{Conclusions}

Despite their potent antitumor activity, NK cells face substantial challenges that hinder their efficacy, such as difficulty in obtaining a large quantity of NK cells, expansion to the clinical scale ex vivo, and the ability to sustain in vivo survival and activity. These challenges can be resolved with the new iPSC-NK tools and genetic engineering approaches. However, the iPSC safety profile, particularly in relation to tumorigenic potential, remains to be understood in sufficient detail for clinical translation. Undoubtedly, NK cells are powerful tools in the armamentarium against cancer due to their direct cytolytic activity against tumor cells. Recently, more treatments using NK cells have shown good results in hematological malignancies and promise a new paradigm for the treatment of solid tumors. Although NK cells have been overlooked in the field, we can target tumor-induced NK cell inhibition to promote the maximum antitumor effect in NK cell-based immunotherapies.

Funding: This research was funded by Chang Gung Memorial Hospital, grant number CMRPD1H0621, CMRPD1K0491 and BMRP440, and Taiwan Ministry of Science and Technology, grant number MOST 109-2320-B-182-037.

Conflicts of Interest: The authors declare no conflict of interest.

\section{References}

1. Chan, M.K.S.; Wong, M.B.F; Nallenthiran, L.; Klokol, D. Live cell therapy: Historical aspects, mechanisms of action, safety and success stories. J. Stem Cell Res. Ther. 2019, 5, 5.

2. Kumar, A.; D'Souza, S.S.; Thakur, A.S. Understanding the Journey of Human Hematopoietic Stem Cell Development. Stem Cells Int. 2019, 2019, 1-13. [CrossRef] [PubMed]

3. Takahashi, K.; Yamanaka, S. Induction of pluripotent stem cells from mouse embryonic and adult fibroblast cultures by defined factors. Cell 2006, 126, 663-676. [CrossRef] [PubMed]

4. Zakrzewski, W.; Dobrzyński, M.; Szymonowicz, M.; Rybak, Z. Stem cells: Past, present, and future. Stem Cell Res. Ther. 2019, 10, 1-22. [CrossRef]

5. Mukhopadhyay, M. Macrophages enter CAR immunotherapy. Nat. Methods 2020, 17, 559. [CrossRef] [PubMed]

6. Mo, F.; Mamonkin, M.; Brenner, M.K.; Heslop, H.E. Taking T-Cell Oncotherapy Off-the-Shelf. Trends Immunol. 2021, 42, $261-272$. [CrossRef] [PubMed]

7. Sadeghzadeh, M.; Bornehdeli, S.; Mohahammadrezakhani, H.; Abolghasemi, M.; Poursaei, E.; Asadi, M.; Zafari, V.; AghebatiMaleki, L.; Shanehbandi, D. Dendritic cell therapy in cancer treatment; the state-of-the-art. Life Sci. 2020, 254, 117580. [CrossRef] [PubMed]

8. Hu, W.; Wang, G.; Huang, D.; Sui, M.; Xu, Y. Cancer Immunotherapy Based on Natural Killer Cells: Current Progress and New Opportunities. Front. Immunol. 2019, 10, 1205. [CrossRef]

9. Chu, D.T.; Nguyen, T.T.; Tien, N.L.B.; Tran, D.K.; Jeong, J.H.; Anh, P.G.; Thanh, V.V.; Truong, D.T.; Dinh, T.C. Recent progress of stem cell therapy in cancer treatment: Molecular mechanisms and potential applications. Cells 2020, 9, 563. [CrossRef]

10. Nianias, A.; Themeli, M. Induced pluripotent stem cell (ipsc)-derived lymphocytes for adoptive cell immunotherapy: Recent advances and challenges. Curr. Hematol. Malig. Rep. 2019, 14, 261-268. [CrossRef]

11. Ronson, A.; Tvito, A.; Rowe, J.M. Treatment of Relapsed/Refractory Acute Lymphoblastic Leukemia in Adults. Curr. Oncol. Rep. 2016, 18, 36. [CrossRef]

12. Park, J.H.; Rivière, I.; Gonen, M.; Wang, X.; Sénéchal, B.; Curran, K.J.; Sauter, C.; Wang, Y.; Santomasso, B.; Mead, E.; et al. Long-Term Follow-up of CD19 CAR Therapy in Acute Lymphoblastic Leukemia. N. Engl. J. Med. 2018, 378, 449-459. [CrossRef]

13. Saetersmoen, M.L.; Hammer, Q.; Valamehr, B.; Kaufman, D.S.; Malmberg, K.J. Off-the-shelf cell therapy with induced pluripotent stem cell-derived natural killer cells. Semin. Immunopathol 2019, 41, 59-68. [CrossRef]

14. Wang, W.; Jiang, J.; Wu, C. CAR-NK for tumor immunotherapy: Clinical transformation and future prospects. Cancer Lett. 2020, 472, 175-180. [CrossRef]

15. Mehta, R.S.; Randolph, B.; Daher, M.; Rezvani, K. NK cell therapy for hematologic malignancies. Int. J. Hematol. 2018, 107, 262-270. [CrossRef]

16. Sakamoto, N.; Ishikawa, T.; Kokura, S.; Okayama, T.; Oka, K.; Ideno, M.; Sakai, F.; Kato, A.; Tanabe, M.; Enoki, T.; et al. Phase I clinical trial of autologous NK cell therapy using novel expansion method in patients with advanced digestive cancer. J. Transl. Med. 2015, 13, 277. [CrossRef] 
17. Miller, J.S.; Soignier, Y.; Panoskaltsis-Mortari, A.; McNearney, S.A.; Yun, G.H.; Fautsch, S.K.; McKenna, D.; Le, C.; DeFor, T.E.; Burns, L.J.; et al. Successful adoptive transfer and in vivo expansion of human haploidentical NK cells in patients with cancer. Blood 2005, 105, 3051-3057. [CrossRef] [PubMed]

18. Rubnitz, J.E.; Inaba, H.; Ribeiro, R.C.; Pounds, S.; Rooney, B.; Bell, T.; Pui, C.-H.; Leung, W. NKAML: A Pilot Study to Determine the Safety and Feasibility of Haploidentical Natural Killer Cell Transplantation in Childhood Acute Myeloid Leukemia. J. Clin. Oncol. 2010, 28, 955-959. [CrossRef] [PubMed]

19. Iliopoulou, E.G.; Kountourakis, P.; Karamouzis, M.V.; Doufexis, D.; Ardavanis, A.; Baxevanis, C.N.; Rigatos, G.; Papamichail, M.; Perez, S.A. A phase I trial of adoptive transfer of allogeneic natural killer cells in patients with advanced non-small cell lung cancer. Cancer Immunol. Immunother. 2010, 59, 1781-1789. [CrossRef] [PubMed]

20. Liu, S.; Galat, V.; Galat, Y.; Lee, Y.K.A.; Wainwright, D.; Wu, J. NK cell-based cancer immunotherapy: From basic biology to clinical development. J. Hematol. Oncol. 2021, 14, 1-17. [CrossRef] [PubMed]

21. Basar, R.; Daher, M.; Rezvani, K. Next-generation cell therapies: The emerging role of CAR-NK cells. Blood Adv. 2020, 4, 5868-5876. [CrossRef]

22. Hodgins, J.J.; Khan, S.T.; Park, M.M.; Auer, R.C.; Ardolino, M. Killers 2.0: NK cell therapies at the forefront of cancer control. J. Clin. Investig. 2019, 129, 3499-3510. [CrossRef]

23. Liu, X.; Huang, J.; Chen, T.; Wang, Y.; Xin, S.; Li, J.; Pei, G.; Kang, J. Yamanaka factors critically regulate the developmental signaling network in mouse embryonic stem cells. Cell Res. 2008, 18, 1177-1189. [CrossRef] [PubMed]

24. Takahashi, K.; Tanabe, K.; Ohnuki, M.; Narita, M.; Ichisaka, T.; Tomoda, K.; Yamanaka, S. Induction of Pluripotent Stem Cells from Adult Human Fibroblasts by Defined Factors. Cell 2007, 131, 861-872. [CrossRef] [PubMed]

25. Okita, K.; Ichisaka, T.; Yamanaka, S. Generation of germline-competent induced pluripotent stem cells. Nat. Cell Biol. 2007, 448, 313-317. [CrossRef] [PubMed]

26. Tomioka, I.; Maeda, T.; Shimada, H.; Kawai, K.; Okada, Y.; Igarashi, H.; Oiwa, R.; Iwasaki, T.; Aoki, M.; Kimura, T.; et al. Generating induced pluripotent stem cells from common marmoset (Callithrix jacchus) fetal liver cells using defined factors, including Lin28. Genes Cells 2010, 15, 959-969. [CrossRef] [PubMed]

27. Feng, B.; Jiang, J.; Kraus, P.; Heng, J.-C.D.; Chan, Y.-S.; Yaw, L.-P.; Zhang, W.; Loh, Y.-H.; Han, J.; Vega, V.B.; et al. Reprogramming of fibroblasts into induced pluripotent stem cells with orphan nuclear receptor Esrrb. Nat. Cell Biol. 2009, 11, 197-203. [CrossRef]

28. Loh, Y.-H.; Agarwal, S.; Park, I.-H.; Urbach, A.; Huo, H.; Heffner, G.C.; Kim, K.; Miller, J.D.; Ng, K.; Daley, G.Q. Generation of induced pluripotent stem cells from human blood. Blood 2009, 113, 5476-5479. [CrossRef] [PubMed]

29. Giorgetti, A.; Montserrat, N.; Aasen, T.; Gonzalez, F.; Rodríguez-Pizà, I.; Vassena, R.; Raya, A.; Boue, S.; Barrero, M.; Corbella, B.A.; et al. Generation of Induced Pluripotent Stem Cells from Human Cord Blood Using OCT4 and SOX2. Cell Stem Cell 2009, 5, 353-357. [CrossRef]

30. Eminli, S.; Foudi, A.; Stadtfeld, M.; Maherali, N.; Ahfeldt, T.; Mostoslavsky, G.; Hock, H.; Hochedlinger, K. Differentiation stage determines potential of hematopoietic cells for reprogramming into induced pluripotent stem cells. Nat. Genet. 2009, 41, 968-976. [CrossRef]

31. Aoki, T.; Ohnishi, H.; Oda, Y.; Tadokoro, M.; Sasao, M.; Kato, H.; Hattori, K.; Ohgushi, H. Generation of Induced Pluripotent Stem Cells from Human Adipose-Derived Stem Cells Without c-MYC. Tissue Eng. Part A 2010, 16, 2197-2206. [CrossRef]

32. Nakagawa, M.; Koyanagi, M.; Tanabe, K.; Takahashi, K.; Ichisaka, T.; Aoi, T.; Okita, K.; Mochiduki, Y.; Takizawa, N.; Yamanaka, S. Generation of induced pluripotent stem cells without Myc from mouse and human fibroblasts. Nat. Biotechnol. 2007, 26, 101-106. [CrossRef]

33. Buganim, Y.; Markoulaki, S.; van Wietmarschen, N.; Hoke, H.; Wu, T.; Ganz, K.; Akhtar-Zaidi, B.; He, Y.; Abraham, B.J.; Porubsky, D.; et al. The Developmental Potential of iPSCs Is Greatly Influenced by Reprogramming Factor Selection. Cell Stem Cell 2014, 15, 295-309. [CrossRef]

34. Utikal, J.; Maherali, N.; Kulalert, W.; Hochedlinger, K. Sox2 is dispensable for the reprogramming of melanocytes and melanoma cells into induced pluripotent stem cells. J. Cell Sci. 2009, 122, 3502-3510. [CrossRef]

35. Kim, J.B.; Greber, B.; Arauzo-Bravo, M.J.; Meyer, J.; Park, K.I.; Zaehres, H.; Scholer, H.R. Direct reprogramming of human neural stem cells by oct 4 . Nature 2009, 461, 649-653. [CrossRef] [PubMed]

36. Liu, H.; Ye, Z.; Kim, Y.; Sharkis, S.; Jang, Y.Y. Generation of endoderm-derived human induced pluripotent stem cells from primary hepatocytes. Hepatology 2010, 51, 1810-1819. [CrossRef]

37. Sugii, S.; Kida, Y.; Kawamura, T.; Suzuki, J.; Vassena, R.; Yin, Y.Q.; Lutz, M.K.; Berggren, W.T.; Izpisua Belmonte, J.C.; Evans, R.M. Human and mouse adipose-derived cells support feeder-independent induction of pluripotent stem cells. Proc. Natl. Acad. Sci. USA 2010, 107, 3558-3563. [CrossRef]

38. Kim, J.B.; Zaehres, H.; Wu, G.; Gentile, L.; Ko, K.; Sebastiano, V.; Araúzo-Bravo, M.J.; Ruau, D.; Han, D.W.; Zenke, M.; et al. Pluripotent stem cells induced from adult neural stem cells by reprogramming with two factors. Nat. Cell Biol. 2008, 454, 646-650. [CrossRef] [PubMed]

39. Park, I.-H.; Arora, N.; Huo, H.; Maherali, N.; Ahfeldt, T.; Shimamura, A.; Lensch, M.W.; Cowan, C.; Hochedlinger, K.; Daley, G.Q. Disease-Specific Induced Pluripotent Stem Cells. Cell 2008, 134, 877-886. [CrossRef] [PubMed]

40. Yu, J.; Vodyanik, M.A.; Smuga-Otto, K.; Antosiewicz-Bourget, J.; Frane, J.L.; Tian, S.; Nie, J.; Jonsdottir, G.A.; Ruotti, V.; Stewart, R.; et al. Induced pluripotent stem cell lines derived from human somatic cells. Science 2007, 318, 1917-1920. [CrossRef] 
41. Omole, A.E.; Fakoya, A.O.J. Ten years of progress and promise of induced pluripotent stem cells: Historical origins, characteristics, mechanisms, limitations, and potential applications. PeerJ 2018, 6, 47. [CrossRef] [PubMed]

42. Rizzino, A. Concise review: The sox2-oct4 connection: Critical players in a much larger interdependent network integrated at multiple levels. Stem Cells 2013, 31, 1033-1039. [CrossRef]

43. Avilion, A.A.; Nicolis, S.K.; Pevny, L.H.; Perez, L.; Vivian, N.; Lovell-Badge, R. Multipotent cell lineages in early mouse development depend on sox2 function. Genes. Dev. 2003, 17, 126-140. [CrossRef]

44. Kopp, J.L.; Ormsbee, B.D.; Desler, M.; Rizzino, A. Small increases in the level of sox2 trigger the differentiation of mouse embryonic stem cells. Stem Cells 2008, 26, 903-911. [CrossRef]

45. Shi, G.; Jin, Y. Role of oct4 in maintaining and regaining stem cell pluripotency. Stem Cell Res. Ther. 2010, 1, 9. [CrossRef] [PubMed]

46. Nichols, J.; Zevnik, B.; Anastassiadis, K.; Niwa, H.; Klewe-Nebenius, D.; Chambers, I.; Schöler, H.; Smith, A. Formation of Pluripotent Stem Cells in the Mammalian Embryo Depends on the POU Transcription Factor Oct4. Cell 1998, 95, $379-391$. [CrossRef]

47. Matz, P.; Adjaye, J. Episomal-based generation of an iPS cell line from human fetal foreskin fibroblasts. Stem Cell Res. 2016, 16, 67-69. [CrossRef]

48. Tashiro, K.; Kawabata, K.; Inamura, M.; Takayama, K.; Furukawa, N.; Sakurai, F.; Katayama, K.; Hayakawa, T.; Furue, M.K.; Mizuguchi, H. Adenovirus Vector-Mediated Efficient Transduction into Human Embryonic and Induced Pluripotent Stem Cells. Cell. Reprogramming 2010, 12, 501-507. [CrossRef]

49. Chen, I.P.; Fukuda, K.; Fusaki, N.; Iida, A.; Hasegawa, M.; Lichtler, A.; Reichenberger, E.J. Induced pluripotent stem cell reprogramming by integration-free sendai virus vectors from peripheral blood of patients with craniometaphyseal dysplasia. Cell Reprogram 2013, 15, 503-513. [CrossRef]

50. Woltjen, K.; Michael, I.; Mohseni, P.; Desai, R.; Mileikovsky, M.; Hämäläinen, R.; Cowling, R.; Wang, W.; Liu, P.; Gertsenstein, M.; et al. piggyBac transposition reprograms fibroblasts to induced pluripotent stem cells. Nat. Cell Biol. 2009, 458, 766-770. [CrossRef]

51. Yu, J.; Chau, K.F.; Vodyanik, M.A.; Jiang, J.; Jiang, Y. Efficient Feeder-Free Episomal Reprogramming with Small Molecules. PLoS ONE 2011, 6, e17557. [CrossRef]

52. Zhou, H.; Wu, S.; Joo, J.Y.; Zhu, S.; Han, D.W.; Lin, T.; Trauger, S.; Bien, G.; Yao, S.; Zhu, Y.; et al. Generation of Induced Pluripotent Stem Cells Using Recombinant Proteins. Cell Stem Cell 2009, 4, 381-384. [CrossRef]

53. Kogut, I.; McCarthy, S.M.; Pavlova, M.; Astling, D.P.; Chen, X.; Jakimenko, A.; Jones, K.L.; Getahun, A.; Cambier, J.C.; Pasmooij, A.M.G.; et al. High-efficiency RNA-based reprogramming of human primary fibroblasts. Nat. Commun. 2018, 9, 745. [CrossRef]

54. Yang, C.S.; Li, Z.; Rana, T.M. Micrornas modulate ips cell generation. RNA 2011, 17, 1451-1460. [CrossRef] [PubMed]

55. Si-Tayeb, K.; Noto, F.K.; Sepac, A.; Sedlic, F.; Bosnjak, Z.J.; Lough, J.W.; Duncan, S.A. Generation of human induced pluripotent stem cells by simple transient transfection of plasmid DNA encoding reprogramming factors. BMC Dev. Biol. 2010, 10, 81. [CrossRef] [PubMed]

56. Narsinh, K.H.; Jia, F.; Robbins, R.C.; Kay, M.A.; Longaker, M.T.; Wu, J.C. Generation of adult human induced pluripotent stem cells using nonviral minicircle DNA vectors. Nat. Protoc. 2010, 6, 78-88. [CrossRef] [PubMed]

57. Woltjen, K.; Hämäläinen, R.; Kibschull, M.; Mileikovsky, M.; Nagy, A. Transgene-Free Production of Pluripotent Stem Cells Using piggyBac Transposons. Cardiovasc. Dev. 2011, 767, 87-103. [CrossRef]

58. Zhou, Y.-Y.; Zeng, F. Integration-free Methods for Generating Induced Pluripotent Stem Cells. Genom. Proteom. Bioinform. 2013, 11, 284-287. [CrossRef] [PubMed]

59. Haridhasapavalan, K.K.; Borgohain, M.P.; Dey, C.; Saha, B.; Narayan, G.; Kumar, S.; Thummer, R.P. An insight into non-integrative gene delivery approaches to generate transgene-free induced pluripotent stem cells. Gene 2019, 686, 146-159. [CrossRef]

60. Shi, Y.; Inoue, H.; Wu, J.C.; Yamanaka, S. Induced pluripotent stem cell technology: A decade of progress. Nat. Rev. Drug Discov. 2017, 16, 115-130. [CrossRef]

61. Stoddard-Bennett, T.; Pera, R.R. Treatment of Parkinson's Disease through Personalized Medicine and Induced Pluripotent Stem Cells. Cells 2019, 8, 26. [CrossRef]

62. Kouroupi, G.; Antoniou, N.; Prodromidou, K.; Taoufik, E.; Matsas, R. Patient-Derived Induced Pluripotent Stem Cell-Based Models in Parkinson's Disease for Drug Identification. Int. J. Mol. Sci. 2020, 21, 7113. [CrossRef]

63. Kondo, T.; Imamura, K.; Funayama, M.; Tsukita, K.; Miyake, M.; Ohta, A.; Woltjen, K.; Nakagawa, M.; Asada, T.; Arai, T.; et al. Ipsc-based compound screening and in vitro trials identify a synergistic anti-amyloid beta combination for alzheimer's disease. Cell Rep. 2017, 21, 2304-2312. [CrossRef]

64. Yahata, N.; Asai, M.; Kitaoka, S.; Takahashi, K.; Asaka, I.; Hioki, H.; Kaneko, T.; Maruyama, K.; Saido, T.C.; Nakahata, T.; et al. Anti-abeta drug screening platform using human ips cell-derived neurons for the treatment of alzheimer's disease. PLoS ONE 2011, 6, e25788. [CrossRef] [PubMed]

65. Pomeshchik, Y.; Puttonen, K.; Kidin, I.; Ruponen, M.; Lehtonen, S.; Malm, T.; Åkesson, E.; Hovatta, O.; Koistinaho, J. Transplanted Human Induced Pluripotent Stem Cell-Derived Neural Progenitor Cells Do Not Promote Functional Recovery of Pharmacologically Immunosuppressed Mice with Contusion Spinal Cord Injury. Cell Transplant. 2015, 24, 1799-1812. [CrossRef]

66. Tsuji, O.; Miura, K.; Okada, Y.; Fujiyoshi, K.; Mukaino, M.; Nagoshi, N.; Kitamura, K.; Kumagai, G.; Nishino, M.; Tomisato, S.; et al. Therapeutic potential of appropriately evaluated safe-induced pluripotent stem cells for spinal cord injury. Proc. Natl. Acad. Sci. USA 2010, 107, 12704-12709. [CrossRef] 
67. Kimbrel, E.A.; Lanza, R. Next-generation stem cells-ushering in a new era of cell-based therapies. Nat. Rev. Drug Discov. 2020, 19, 463-479. [CrossRef] [PubMed]

68. Oji, A.; Noda, T.; Fujihara, Y.; Miyata, H.; Kim, Y.J.; Muto, M.; Nozawa, K.; Matsumura, T.; Isotani, A.; Ikawa, M. CRISPR/Cas9 mediated genome editing in ES cells and its application for chimeric analysis in mice. Sci. Rep. 2016, 6, 31666. [CrossRef] [PubMed]

69. Ferreccio, A.; Mathieu, J.; Detraux, D.; Logeshwaran, S.; Cavanaugh, C.; Sopher, B.; Fischer, K.; Bello, T.; Hussein, A.M.; Levy, S.; et al. Inducible CRISPR genome editing platform in naive human embryonic stem cells reveals JARID2 function in self-renewal. Cell Cycle 2018, 17, 535-549. [CrossRef] [PubMed]

70. Grobarczyk, B.; Franco, B.; Hanon, K.; Malgrange, B. Generation of isogenic human ips cell line precisely corrected by genome editing using the crispr/cas9 system. Stem Cell Rev. Rep. 2015, 11, 774-787. [CrossRef] [PubMed]

71. Huang, X.; Wang, Y.; Yan, W.; Smith, C.; Ye, Z.; Wang, J.; Gao, Y.; Mendelsohn, L.; Cheng, L. Production of gene-corrected adult beta globin protein in human erythrocytes differentiated from patient ipscs after genome editing of the sickle point mutation. Stem Cells 2015, 33, 1470-1479. [CrossRef]

72. Jiang, F.; Doudna, J.A. CRISPR-Cas9 Structures and Mechanisms. Annu. Rev. Biophys. 2017, 46, 505-529. [CrossRef]

73. Maeder, M.L.; Gersbach, C.A. Genome-editing Technologies for Gene and Cell Therapy. Mol. Ther. 2016, 24, 430-446. [CrossRef]

74. Zhang, F. CRISPR/Cas9: Prospects and Challenges. Hum. Gene Ther. 2015, 26, 409-410. [CrossRef]

75. Bak, R.O.; Dever, D.P.; Porteus, M.H. CRISPR/Cas9 genome editing in human hematopoietic stem cells. Nat. Protoc. 2018, 13, 358-376. [CrossRef]

76. Frangoul, H.; Altshuler, D.; Cappellini, M.D.; Chen, Y.S.; Domm, J.; Eustace, B.K.; Foell, J.; de la Fuente, J.; Grupp, S.; Handgretinger, R.; et al. Crispr-cas9 gene editing for sickle cell disease and beta-thalassemia. N. Engl. J. Med. 2021, 384, $252-260$. [CrossRef] [PubMed]

77. Kantor, A.; McClements, M.E.; MacLaren, R.E. CRISPR-Cas9 DNA Base-Editing and Prime-Editing. Int. J. Mol. Sci. 2020, 21, 6240. [CrossRef] [PubMed]

78. Yang, H.; Ren, S.; Yu, S.; Pan, H.; Li, T.; Ge, S.; Zhang, J.; Xia, N. Methods favoring homology-directed repair choice in response to crispr/cas9 induced-double strand breaks. Int. J. Mol. Sci. 2020, 21, 6461. [CrossRef]

79. Brinkman, E.K.; Chen, T.; de Haas, M.; Holland, H.A.; Akhtar, W.; van Steensel, B. Kinetics and fidelity of the repair of cas9-induced double-strand DNA breaks. Mol. Cell 2018, 70, 801-813.e806. [CrossRef] [PubMed]

80. Moradi, S.; Mahdizadeh, H.; Šarić, T.; Kim, J.; Harati, J.; Shahsavarani, H.; Greber, B.; Iv, J.B.M. Research and therapy with induced pluripotent stem cells (iPSCs): Social, legal, and ethical considerations. Stem Cell Res. Ther. 2019, 10, 341. [CrossRef]

81. Kanemura, H.; Go, M.J.; Shikamura, M.; Nishishita, N.; Sakai, N.; Kamao, H.; Mandai, M.; Morinaga, C.; Takahashi, M.; Kawamata, S. Tumorigenicity studies of induced pluripotent stem cell (ipsc)-derived retinal pigment epithelium (rpe) for the treatment of age-related macular degeneration. PLoS ONE 2014, 9, e85336. [CrossRef]

82. Sugita, S. Retinal regeneration with iPS cells—Clinical trials for retinal degenerative disorders. Jpn. J. Clin. Immunol. 2015, 38, 7. [CrossRef]

83. Sugita, S.; Iwasaki, Y.; Makabe, K.; Kamao, H.; Mandai, M.; Shiina, T.; Ogasawara, K.; Hirami, Y.; Kurimoto, Y.; Takahashi, M. Successful Transplantation of Retinal Pigment Epithelial Cells from MHC Homozygote iPSCs in MHC-Matched Models. Stem Cell Rep. 2016, 7, 635-648. [CrossRef]

84. Koga, K.; Wang, B.; Kaneko, S. Current status and future perspectives of HLA-edited induced pluripotent stem cells. Inflamm. Regen. 2020, 40, 23. [CrossRef]

85. Umekage, M.; Sato, Y.; Takasu, N. Overview: An iPS cell stock at CiRA. Inflamm. Regen. 2019, 39, 17. [CrossRef]

86. Deinsberger, J.; Reisinger, D.; Weber, B. Global trends in clinical trials involving pluripotent stem cells: A systematic multi-database analysis. NPJ Regen. Med. 2020, 5, 15. [CrossRef]

87. Nagoshi, N.; Tsuji, O.; Nakamura, M.; Okano, H. Cell therapy for spinal cord injury using induced pluripotent stem cells. Regen. Ther. 2019, 11, 75-80. [CrossRef]

88. Tewarie, R.S.N.; Hurtado, A.; Bartels, R.H.; Grotenhuis, A.; Martin Oudega, P. Stem cell-based therapies for spinal cord injury. J. Spinal. Cord. Med. 2009, 32, 10.

89. Kobayashi, Y.; Okada, Y.; Itakura, G.; Iwai, H.; Nishimura, S.; Yasuda, A.; Nori, S.; Hikishima, K.; Konomi, T.; Fujiyoshi, K.; et al. Pre-evaluated safe human iPSC-derived neural stem cells promote functional recovery after spinal cord injury in common marmoset without tumorigenicity. PLOS ONE 2012, 7, e52787.

90. Nori, S.; Okada, Y.; Yasuda, A.; Tsuji, O.; Takahashi, Y.; Kobayashi, Y.; Fujiyoshi, K.; Koike, M.; Uchiyama, Y.; Ikeda, E.; et al. Grafted human-induced pluripotent stem-cell-derived neurospheres promote motor functional recovery after spinal cord injury in mice. Proc. Natl. Acad. Sci. USA 2011, 108, 16825-16830. [CrossRef] [PubMed]

91. Tsuji, O.; Sugai, K.; Yamaguchi, R.; Tashiro, S.; Nagoshi, N.; Kohyama, J.; Iida, T.; Ohkubo, T.; Itakura, G.; Isoda, M.; et al. Concise Review: Laying the Groundwork for a First-In-Human Study of an Induced Pluripotent Stem Cell-Based Intervention for Spinal Cord Injury. Stem Cells 2019, 37, 6-13. [CrossRef]

92. Eintracht, J.; Toms, M.; Moosajee, M. The Use of Induced Pluripotent Stem Cells as a Model for Developmental Eye Disorders. Front. Cell. Neurosci. 2020, 14, 265. [CrossRef]

93. Senju, S.; Matsunaga, Y.; Fukushima, S.; Hirata, S.; Motomura, Y.; Fukuma, D.; Matsuyoshi, H.; Nishimura, Y. Immunotherapy with pluripotent stem cell-derived dendritic cells. Semin. Immunopathol 2011, 33, 603-612. [CrossRef] [PubMed] 
94. Kitadani, J.; Ojima, T.; Iwamoto, H.; Tabata, H.; Nakamori, M.; Nakamura, M.; Hayata, K.; Katsuda, M.; Miyajima, M.; Yamaue, H. Cancer vaccine therapy using carcinoembryonic antigen-expressing dendritic cells generated from induced pluripotent stem cells. Sci. Rep. 2018, 8, 4569. [CrossRef] [PubMed]

95. Maeda, T.; Nagano, S.; Ichise, H.; Kataoka, K.; Yamada, D.; Ogawa, S.; Koseki, H.; Kitawaki, T.; Kadowaki, N.; Takaori-Kondo, A.; et al. Regeneration of cd8alphabeta t cells from t-cell-derived ipsc imparts potent tumor antigen-specific cytotoxicity. Cancer Res. 2016, 76, 6839-6850. [CrossRef] [PubMed]

96. Themeli, M.; Kloss, C.C.; Ciriello, G.; Fedorov, V.D.; Perna, F.; Gonen, M.; Sadelain, M. Generation of tumor-targeted human T lymphocytes from induced pluripotent stem cells for cancer therapy. Nat. Biotechnol. 2013, 31, 928-933. [CrossRef] [PubMed]

97. Hermanson, D.L.; Bendzick, L.; Pribyl, L.; McCullar, V.; Vogel, R.I.; Miller, J.S.; Geller, M.A.; Kaufman, D.S. Induced pluripotent stem cell-derived natural killer cells for treatment of ovarian cancer. Stem Cells 2016, 34, 93-101. [CrossRef] [PubMed]

98. Ng, E.S.; Davis, R.; Stanley, E.G.; Elefanty, A.G. A protocol describing the use of a recombinant protein-based, animal product-free medium (apel) for human embryonic stem cell differentiation as spin embryoid bodies. Nat. Protoc. 2008, 3, 768-776. [CrossRef] [PubMed]

99. Iriguchi, S.; Yasui, Y.; Kawai, Y.; Arima, S.; Kunitomo, M.; Sato, T.; Ueda, T.; Minagawa, A.; Mishima, Y.; Yanagawa, N.; et al. A clinically applicable and scalable method to regenerate T-cells from iPSCs for off-the-shelf T-cell immunotherapy. Nat. Commun. 2021, 12, 430. [CrossRef] [PubMed]

100. Neelapu, S.S.; Locke, F.L.; Bartlett, N.L.; Lekakis, L.J.; Miklos, D.B.; Jacobson, C.A.; Braunschweig, I.; Oluwole, O.O.; Siddiqi, T.; Lin, Y.; et al. Axicabtagene Ciloleucel CAR T-Cell Therapy in Refractory Large B-Cell Lymphoma. N. Engl. J. Med. 2017, 377, 2531-2544. [CrossRef]

101. Shankar, K.; Capitini, C.M.; Saha, K. Genome engineering of induced pluripotent stem cells to manufacture natural killer cell therapies. Stem Cell Res. Ther. 2020, 11, 234. [CrossRef]

102. Morvan, M.; Lanier, L.L. NK cells and cancer: You can teach innate cells new tricks. Nat. Rev. Cancer 2016, 16, 7-19. [CrossRef]

103. Bachanova, V.; Cooley, S.; DeFor, T.E.; Verneris, M.R.; Zhang, B.; McKenna, D.H.; Curtsinger, J.; Panoskaltsis-Mortari, A.; Lewis, D.; Hippen, K.; et al. Clearance of acute myeloid leukemia by haploidentical natural killer cells is improved using IL-2 diphtheria toxin fusion protein. Blood 2014, 123, 3855-3863. [CrossRef] [PubMed]

104. Zeng, J.; Tang, S.Y.; Toh, L.L.; Wang, S. Generation of “Off-the-Shelf” Natural Killer Cells from Peripheral Blood Cell-Derived Induced Pluripotent Stem Cells. Stem Cell Rep. 2017, 9, 1796-1812. [CrossRef] [PubMed]

105. D'Souza, S.S.; Maufort, J.; Kumar, A.; Zhang, J.; Smuga-Otto, K.; Thomson, J.A.; Slukvin, I.I. Gsk3beta inhibition promotes efficient myeloid and lymphoid hematopoiesis from non-human primate-induced pluripotent stem cells. Stem Cell Rep. 2016, 6, 243-256. [CrossRef] [PubMed]

106. Matsubara, H.; Niwa, A.; Nakahata, T.; Saito, M.K. Induction of human pluripotent stem cell-derived natural killer cells for immunotherapy under chemically defined conditions. Biochem. Biophys. Res. Commun. 2019, 515, 1-8. [CrossRef]

107. Oh, S.; Lee, J.-H.; Kwack, K.; Choi, S.-W. Natural Killer Cell Therapy: A New Treatment Paradigm for Solid Tumors. Cancers 2019, 11, 1534. [CrossRef] [PubMed]

108. Trabanelli, S.; Gomez-Cadena, A.; Salomé, B.; Michaud, K.; Mavilio, D.; Landis, B.N.; Jandus, P.; Jandus, C. Human innate lymphoid cells (ILCs): Toward a uniform immune-phenotyping. Cytom. Part B Clin. Cytom. 2018, 94, 392-399. [CrossRef]

109. Chiossone, L.; Dumas, P.-Y.; Vienne, M.; Vivier, E. Natural killer cells and other innate lymphoid cells in cancer. Nat. Rev. Immunol. 2018, 18, 671-688. [CrossRef]

110. Zhu, L.; Kalimuthu, S.; Oh, J.M.; Gangadaran, P.; Baek, S.H.; Jeong, S.Y.; Lee, S.W.; Lee, J.; Ahn, B.C. Enhancement of antitumor potency of extracellular vesicles derived from natural killer cells by il-15 priming. Biomaterials 2019, 190-191, 38-50. [CrossRef]

111. O'Brien, K.L.; Finlay, D.K. Immunometabolism and natural killer cell responses. Nat. Rev. Immunol. 2019, 19, 282-290. [CrossRef]

112. Anft, M.; Netter, P.; Urlaub, D.; Prager, I.; Schaffner, S.; Watzl, C. Nk cell detachment from target cells is regulated by successful cytotoxicity and influences cytokine production. Cell Mol. Immunol. 2020, 17, 347-355. [CrossRef]

113. Michel, T.; Poli, A.; Cuapio, A.; Briquemont, B.; Iserentant, G.; Ollert, M.; Zimmer, J. Human CD56bright NK Cells: An Update. J. Immunol. 2016, 196, 2923-2931. [CrossRef] [PubMed]

114. Yu, J.; Freud, A.G.; Caligiuri, M.A. Location and cellular stages of natural killer cell development. Trends Immunol. 2013, 34, 573-582. [CrossRef] [PubMed]

115. Poli, A.; Michel, T.; Theresine, M.; Andres, E.; Hentges, F.; Zimmer, J. Cd56bright natural killer (nk) cells: An important nk cell subset. Immunology 2009, 126, 458-465. [CrossRef] [PubMed]

116. Zhu, H.; Kaufman, D.S. Engineered human pluripotent stem cell-derived natural killer cells: The next frontier for cancer immunotherapy. Blood Sci. 2019, 1, 4-11. [CrossRef]

117. Malhotra, A.; Shanker, A. NK cells: Immune cross-talk and therapeutic implications. Immunotherapy 2011, 3, 1143-1166. [CrossRef]

118. Zamai, L.; Ponti, C.; Mirandola, P.; Gobbi, G.; Papa, S.; Galeotti, L.; Cocco, L.; Vitale, M. NK cells and cancer. J. Immunol. 2007, 178, 4011-4016. [CrossRef]

119. Di Vito, C.; Mikulak, J.; Zaghi, E.; Pesce, S.; Marcenaro, E.; Mavilio, D. NK cells to cure cancer. Semin. Immunol. $2019,41,101272$. [CrossRef]

120. Nigro, C.L.; Macagno, M.; Sangiolo, D.; Bertolaccini, L.; Aglietta, M.; Merlano, M.C. NK-mediated antibody-dependent cellmediated cytotoxicity in solid tumors: Biological evidence and clinical perspectives. Ann. Transl. Med. 2019, 7, 105. [CrossRef] 
121. Lu, R.-M.; Hwang, Y.-C.; Liu, I.-J.; Lee, C.-C.; Tsai, H.-Z.; Li, H.-J.; Wu, H.-C. Development of therapeutic antibodies for the treatment of diseases. J. Biomed. Sci. 2020, 27, 1-30. [CrossRef] [PubMed]

122. Dixon, K.J.; Wu, J.; Walcheck, B. Engineering anti-tumor monoclonal antibodies and fc receptors to enhance adcc by human nk cells. Cancers (Basel) 2021, 13, 312. [CrossRef] [PubMed]

123. Wang, W.; Erbe, A.K.; Hank, J.A.; Morris, Z.S.; Sondel, P.M. NK cell-mediated antibody-dependent cellular cytotoxicity in cancer immunotherapy. Front. Immunol. 2015, 6, 368. [CrossRef] [PubMed]

124. Minetto, P.; Guolo, F.; Pesce, S.; Greppi, M.; Obino, V.; Ferretti, E.; Sivori, S.; Genova, C.; Lemoli, R.M.; Marcenaro, E. Harnessing nk cells for cancer treatment. Front. Immunol 2019, 10, 2836. [CrossRef]

125. Barrow, A.D.; Martin, C.J.; Colonna, M. The Natural Cytotoxicity Receptors in Health and Disease. Front. Immunol. 2019, 10, 909. [CrossRef] [PubMed]

126. Smyth, M.J.; Swann, J.; Kelly, J.M.; Cretney, E.; Yokoyama, W.M.; Diefenbach, A.; Sayers, T.J.; Hayakawa, Y. Nkg2d recognition and perforin effector function mediate effective cytokine immunotherapy of cancer. J. Exp. Med. 2004, 200, 1325-1335. [CrossRef] [PubMed]

127. Goldenson, B.H.; Zhu, H.; Wang, Y.M.; Heragu, N.; Bernareggi, D.; Ruiz-Cisneros, A.; Bahena, A.; Ask, E.H.; Hoel, H.J.; Malmberg, K.J.; et al. Umbilical cord blood and ipsc-derived natural killer cells demonstrate key differences in cytotoxic activity and kir profiles. Front. Immunol. 2020, 11, 561553. [CrossRef]

128. Konjević, G.; Vuletić, A.; Martinović, K.M.; Džodić, R. The Role of Activating and Inhibitory NK Cell Receptors in Antitumor Immune Response. Nat. Kill. Cells 2017, 49-65. [CrossRef]

129. Sivori, S.; Vacca, P.; Del Zotto, G.; Munari, E.; Mingari, M.C.; Moretta, L. Human NK cells: Surface receptors, inhibitory checkpoints, and translational applications. Cell. Mol. Immunol. 2019, 16, 430-441. [CrossRef]

130. Terunuma, H.; Deng, X.; Dewan, Z.; Fujimoto, S.; Yamamoto, N. Potential role of nk cells in the induction of immune responses: Implications for nk cell-based immunotherapy for cancers and viral infections. Int. Rev. Immunol. 2008, 27, 93-110. [CrossRef]

131. Larsen, S.K.; Gao, Y.; Basse, P.H. Nk cells in the tumor microenvironment. Crit. Rev. Oncog. 2014, 19, 91-105. [CrossRef]

132. Bald, T.; Krummel, M.F.; Smyth, M.J.; Barry, K.C. The NK cell-cancer cycle: Advances and new challenges in NK cell-based immunotherapies. Nat. Immunol. 2020, 21, 835-847. [CrossRef] [PubMed]

133. Yao, X.; Matosevic, S. Chemokine networks modulating natural killer cell trafficking to solid tumors. Cytokine Growth Factor Rev. 2021, 59, 36-45. [CrossRef] [PubMed]

134. Robertson, M.J. Role of chemokines in the biology of natural killer cells. J. Leukoc. Biol. 2002, 71, 173-183. [PubMed]

135. Yang, H.; Zhang, Q.; Xu, M.; Wang, L.; Chen, X.; Feng, Y.; Li, Y.; Zhang, X.; Cui, W.; Jia, X. CCL2-CCR2 axis recruits tumor associated macrophages to induce immune evasion through PD-1 signaling in esophageal carcinogenesis. Mol. Cancer 2020, 19, 41. [CrossRef] [PubMed]

136. Heiskala, M.; Leidenius, M.; Joensuu, K.; Heikkilä, P. High expression of CCL2 in tumor cells and abundant infiltration with CD14 positive macrophages predict early relapse in breast cancer. Virchows Arch. 2019, 474, 3-12. [CrossRef]

137. Terrén, I.; Orrantia, A.; Vitallé, J.; Zenarruzabeitia, O.; Borrego, F. NK Cell Metabolism and Tumor Microenvironment. Front. Immunol. 2019, 10, 2278. [CrossRef] [PubMed]

138. Fehniger, T.A.; Bluman, E.M.; Porter, M.M.; Mrozek, E.; Cooper, M.; VanDeusen, J.B.; Frankel, S.R.; Stock, W.; Caligiuri, M.A. Potential mechanisms of human natural killer cell expansion in vivo during low-dose IL-2 therapy. J. Clin. Investig. 2000, 106, 117-124. [CrossRef]

139. Felices, M.; Lenvik, A.J.; McElmurry, R.; Chu, S.; Hinderlie, P.; Bendzick, L.; Geller, M.A.; Tolar, J.; Blazar, B.R.; Miller, J.S. Continuous treatment with IL-15 exhausts human NK cells via a metabolic defect. JCI Insight 2018, 3, 3. [CrossRef]

140. Bierie, B.; Moses, H.L. Tumour microenvironment: Tgfbeta: The molecular jekyll and hyde of cancer. Nat. Rev. Cancer 2006, 6, 506-520. [CrossRef]

141. Li, Y.; Hermanson, D.L.; Moriarity, B.S.; Kaufman, D.S. Human ipsc-derived natural killer cells engineered with chimeric antigen receptors enhance anti-tumor activity. Cell Stem Cell 2018, 23, 181-192.e185. [CrossRef] [PubMed]

142. Bollino, D.; Webb, T.J. Chimeric antigen receptor-engineered natural killer and natural killer t cells for cancer immunotherapy. Transl. Res. 2017, 187, 32-43. [CrossRef] [PubMed]

143. Ueda, T.; Kumagai, A.; Iriguchi, S.; Yasui, Y.; Miyasaka, T.; Nakagoshi, K.; Nakane, K.; Saito, K.; Takahashi, M.; Sasaki, A.; et al. Non-clinical efficacy, safety and stable clinical cell processing of induced pluripotent stem cell-derived anti-glypican-3 chimeric antigen receptor-expressing natural killer/innate lymphoid cells. Cancer Sci. 2020, 111, 1478-1490. [CrossRef] [PubMed] 